\title{
Unsettling Oceania, 250 Years Later: Introduction
}

\section{Christine Lorre-Johnston}

\section{(2) OpenEdition}

1 Journals

Electronic version

URL: https://journals.openedition.org/ces/393

DOI: $10.4000 /$ ces.393

ISSN: 2534-6695

\section{Publisher}

SEPC (Société d'études des pays du Commonwealth)

\section{Printed version}

Date of publication: 30 November 2018

Number of pages: $75-82$

ISSN: 2270-0633

\section{Electronic reference}

Christine Lorre-Johnston, "Unsettling Oceania, 250 Years Later: Introduction", Commonwealth Essays and Studies [Online], 41.1 | 2018, Online since 05 November 2019, connection on 23 August 2021. URL: http://journals.openedition.org/ces/393 ; DOI: https://doi.org/10.4000/ces.393

\section{(c) (i) () $\ominus$}

Commonwealth Essays and Studies is licensed under a Licence Creative Commons Attribution - Pas d'Utilisation Commerciale - Pas de Modification 4.0 International. 


\section{Unsettling Oceania, 250 Years Later Introduction}

This issue is timed for the 250th anniversary of Captain James Cook's first voyage to the Pacific in search of terra australis incognita in 1768. Several events have been organised to mark this anniversary, including the "Oceania" exhibition at the Royal Academy in London, which addresses the question of how the Pacific has been perceived over time. This major exhibition is worth reflecting on to see what bearings it can offer us as we navigate the history and concepts linked to Oceania. The "Oceania" exhibition opened in September 2018, displaying varied art works from the Pacific. (As it happens the Royal Academy was founded the same year as that first voyage, making it a particularly relevant site for the exhibition.) The display will open in March 2019 at the Musée du quai Branly - Jacques Chirac, a Paris museum dedicated to Indigenous arts and cultures of Africa, Oceania, Asia, and the Americas. This is a timely exhibition, long in preparation, ${ }^{1}$ that foregrounds the culture and arts of Indigenous peoples from the Pacific, giving them prime location in two European capital cities of nations that are former colonisers. On 24 September, an official opening ceremony took place in London, with a ceremonial welcome by Ngāti Rānana (the "London tribe," Rānana being the Māori transliteration for London) representing the Royal Academy. Other countries of Oceania also performed outside the building. A private blessing of the items on display, many of which are considered taonga (treasures) by the people they come from, was conducted in the exhibition galleries. ${ }^{2}$

Earlier in the year, the British Library put on an exhibition devoted to Captain Cook's voyages. The editors of the catalogue recall Cook's long-lasting status as a hero of Empire, before pointing out that "As the narrative of Europe's 'discovery' became increasingly challenged, greater interest was taken in the original human settlement of the Pacific" (Frame and Walker 12). A similar dynamic of reassessment characterises the Oceania exhibition: in a context in which the "project of 'decolonisation' [...] defines and challenges our present epoch," the exhibition was an occasion for renewed discussions about "the complex modernities of Indigenous people's encounters with the West" (Brunt and Thomas 27, 23). The exhibition sheds a nuanced light on the notion of decolonisation. ${ }^{3}$ The Pacific culture of gift-giving, in particular, complicates the presence of Indigenous objects in Western collections and shows that they are the sign of

1. The Oceania project that took place in Wellington in 2011 simultaneously at the City Gallery and the Museum of New Zealand Te Papa Tongarewa may be seen as a precursor to the London 2018 Oceania exhibition. See the catalogue, Oceania: Imagining the Pacific.

2. See the coverage of the event in the Guardian <https://www.theguardian.com/artanddesign/2017/sep/07/ royal-academy-arts-oceania-exhibition-south-pacific $>$, in the New Zealand Herald <https://www.nzherald.co.nz/nz/ news/article.cfm?c_id=1\&objectid=12130951>, and the page on the Royal Academy of Arts website <https://www. royalacademy.org.uk/exhibition/oceania>.

3. In contrast to a balanced approach of the complex notion of decolonisation, a manifesto signed by 80 French intellectuals and published on 28 November 2018 in Le Point denounces decolonisation as a "hegemonic strategy" that reactivates the divisive notion of race in the name of emancipation and whose proponents refuse to engage in contradictory debate. This "manifesto" can only be seen as the expression of another conspiracy theory, as Jean-Marc Moura pointed out during a seminar on Walter Mignolo's works held at University Paris Nanterre on 10 December 2018. See the manifesto at <https://www.lepoint.fr/politique/le-decolonialisme-une-strategie-hegemonique-l-appel- 
elaborate exchanges. In this vein, the multi-media installation artist Lisa Reihana, in In Pursuit of Venus, a major work that is part of the Oceania exhibition, revisits "Les Sauvages de la Mer Pacifique," an 1804-05 decorative wallpaper by Josef Dufour and Jean-Gabriel Charvet, that represents a number of idealised, exotic scenes of encounter between Europeans and Oceanian peoples. Her work, a video that unrolls on a wide screen and mixes set backdrops and cinematic animation, explores the complexity of viewpoint, as Reihana explains: "Well aware of the slippery nature of viewpoints and truth, I deliberately included scenes that show the risks of encounter and cultural conflicts" (16). It is through such historical objects as those presented in the Oceania exhibition, or revisited in Reihana's video installation, the knowledge of their history, and a critical perspective on them, that a way into the future can be more clearly traced. As Felwine Sarr and Bénédicte Savoy write in their report on the restitution of art objects to Benin by the French government, thinking through the process of restitution, as an act of decolonisation, implies much more than an exploration of the past; it is first and foremost about building bridges towards more equal relations in future, a gesture guided by dialogue, polyphony and exchange. ${ }^{4}$

On the occasion of the official opening of the Oceania exhibition, Hon. Carmel Sepuloni, New Zealand's Associate Minister for Arts, Culture and Heritage, and for Pacific Peoples, observed that "The themes of the exhibition include journeying and encounters as well as contemporary issues for Pacific nations such as climate change, regional security and sustainable development." Considering Oceanian culture is indeed an opportunity to reflect on journeys and encounter, movement and migration, in the past and in our times, a reflection that is inseparable from one on our relation to the ocean and, more at large, to the natural environment. When a beluga whale, an Arctic species, was spotted in the Thames near Gravesend, east of London, the day of the opening ceremony of the Oceania exhibition, Sepuloni interpreted the coincidence as "a blessing." This unprecedented event certainly acts as a reminder of the power of the whale as an animal that challenges our perception (see Huggan 2018), and more broadly, of the need to rethink our relationship with nature and with other species. The beluga whale had to be led out of the Thames estuary, as it was too disoriented to find its way, just as we humans are largely at a loss about our current environmental situation.

Earlier in the year, in July, a southern right whale spent a week in Wellington harbour, less than a kilometre as the crow flies from Parliament House. A Guardian article ob-served that such whales, known as tohora in New Zealand, used to be a common sight in Wellington harbour but were brought to the brink of extinction after 150 years of wha-

de-80-intellectuels-28-11-2018-2275104_20.php?fbclid=IwAR33knJqQJT3311-oUqLW9Bt2KoAYTorG-4wgu0KcjzEjEBkteBUEPxcGnA>.

4. "Penser les restitutions implique pourtant bien davantage qu'une seule exploration du passé : il s'agit avant tout de bâtir des ponts vers des relations futures plus équitables. Guidé par le dialogue, la polyphonie et l'échange, le geste de la restitution ne saurait en outre être considéré comme un acte dangereux d'assignation identitaire ou de cloisonnement territorial des biens culturels. Il invite tout au contraire à ouvrir la signification des objets, et à offrir à «l'universel » auquel ils sont si souvent associés en Europe la possibilité d'être éprouvé ailleurs."

See Felwine Sarr and Bénédicte Savoy, Restituer le patrimoine africain : vers une nouvelle éthique relationnelle, a governmentordered report that was officially handed in to President Macron on 23 November 2018.

5. New Zealand Herald 24 September 2018, <https://www.nzherald.co.nz/nz/news/article.cfm?c_id=1\&objectid= $12130951>$

6. Hon. Carmel Sepuloni commented on the event at a reception in her honor at the residence of the New Zealand Ambassador to France in Paris on 26 September 2018. Warmest thanks to H.E. Jane Coombs for inviting me to join the reception. 
ling. ${ }^{7}$ Like the Beluga whale in the Thames, the southern right whale that strayed into Wellington harbour was disoriented, yet stayed there for a week, "charming the locals," until it swam away again. Straying or endangered whales remind us that the ocean, as part of our environment, binds all living species. As Lana Lopesi and Emma Ng point out, Te Moana Nui a Kiwa, "the great ocean of Kiwa, the legendary Polynesian explorer and guardian of the sea" in Māori (Keown 11), is traditionally a connector and an ancestor. Imperialism in the Moana, the ocean continent, however, created false divides between islands and separated peoples. But Moana peoples now play a part in drawing our attention to the unifying role of the ocean. ${ }^{8}$ And in the global age, the ocean continent's influence spreads well beyond Oceania.

Preparing a journal issue on Oceania is like casting a wide net and waiting to see what it brings in - the journal issue can accommodate a small sample, given the heterogeneity of Oceanic cultures, but hopefully one that is evocative of the lively creativity that is to be found out there. The term Oceania as it is used here needs further clarification, as it may encompass various elements. Overall it is more broadly used in French and other European languages than in English where "Pacific Islands" is the preferred contemporary appellation. Yet the term Oceania in English was reassessed and given a new turn in two landmark essays, "Towards a New Oceania" (1976) by the Samoan writer Albert Wendt, and "The Ocean in Us" (1997) by the Tongan anthropologist and writer Epeli Hau'ofa. Wendt argued for "a quest [...] for a new Oceania," "a quest not for the revival of our past cultures but for the creation of new cultures which are free of the taint of colonialism and based firmly on our own pasts" (53). For Hau'ofa, the appellation is meaningful as "Oceania' denotes a sea of islands with their inhabitants" (32), thus drawing attention to the sea and its role as an element that binds, more than it separates, the various peoples that live there. The word is charged with a spirit of decolonisation through reassessment.

Oceania sometimes includes the island-continent of Australia, and such is the case in this issue. Oceania in this sense offers two seemingly opposed directions; one that draws attention to the centrality of the sea for Pacific Islanders, and emphasises the relations among them, looking outwards, and the other, in Australia, where the pull is inwards, towards the centre and the desert. Yet, due in particular to the historical links that bind them, the two directions are complementary.

In terms of cultural dynamics, mapping out the cultural life of Oceania implies dealing with both remarkable fluidity, but also the presence of a number of active centres, as Michelle Keown observes. She distinguishes between "relatively affluent metropolitan centres in the Pacific (such as Aotearoa New Zealand and Hawaici)" - and although her study does not include it, one could add Australia - that "have spawned a rich diversity of writers from various ethnic and socio-economic backgrounds," and countries that "generally possess more fragile economies with far fewer resources for writing and pu-

7. <https://www.theguardian.com/world/2018/jul/06/frolicking-southern-right-whale-charms-new-zealand-capital $>$.

8. See Lana Lopesi and Emma Ng, "The Pacific - Divider or Connector?" < https://www.bwb.co.nz/news/events/ winter-series-pacific- $\%$ E2\%80\%93-divider-or-connector-lana-lopesi-and-emma-ng-conversation>. 
blishing." She points out how the University of the South Pacific (USP), established in 1968 in Fiji, now with a dozen locations in Pacific Island countries, "has brought together Indigenous peoples from eleven former British colonies in the South Pacific" and has "served as an important locus of creativity for writers from these nations, fostering many key authors, publications, and writers' collectives over the decades" (6). Wendt and Hau'ofa were both involved in the activities of the USP. The University of Papua New Guinea (UPNG), which was founded in 1965 when the country was still under Australian administration, has played a similar role. These cultural centres generate a dynamic that shapes what Oceanic culture is about.

It has been argued that when people talk of Pacific Islands, they often actually refer essentially to Polynesia. The term refers to one of the three areas into which the Pacific was divided by the French explorer Jules-Sébastien-César Dumont d'Urville in 1832, based on two different racial types: one found in Polynesia ("many islands") and Micronesia ("small islands"), and the other in Melanesia ("black islands"; see Keown 13-4). As Nicholas Thomas points out in Oceania: Imagining the Pacific, in recent years, Aotearoa New Zealand has played a key role as a cultural centre for the Pacific, but "Pacific" in this context often means essentially Polynesia, rather than Micronesia and Melanesia. Thomas quotes Hau'ofa's comment that one of the advantages of the Oceania Centre at the USP in Fiji is that it succeeded in bringing together Melanesians and Polynesians. Similarly, Port Moresby in Papua New Guinea acted "as a kind of counter-weight to Auckland" (51). Reuben Friend in the same book remarks: "In Aotearoa New Zealand we often refer to 'the Pacific' when really we mean Polynesia. In doing so, we privilege this most central region of Oceania of which we are the most southern constituents" (69). Six articles in this issue deal with the literature and culture of Australia; two of them consider Aotearoa New Zealand, and three others, some of the Pacific Islands that were historically integrated into their sphere of influence, whether in Polynesia (Samoa) or Melanesia (Fiji), as well as others beyond that, in Micronesia (Marshall Islands, Guam). This opening onto the Pacific that is not Australia or New Zealand and parts of Polynesia is an essential decentering of our perspective on "Oceania."

In the introduction to The Novel in Australia, Canada, New Zealand, and the South Pacific since 1950, Coral Ann Howells, Paul Sharrad and Gerry Turcotte adopt a more restrictive definition of the term. They consider "the region loosely defined as Oceania" as the zone encompassing "at least three major distinct ethnic-linguistic groups (termed, in Eurocentric language, Melanesian, Polynesian, and Micronesian)" and observe that:

The South Pacific islands were never white settler colonies and some retained effective self-control throughout, while others still remained colonies long after their neighbours achieved independence. [...] The emergence of fiction in English in this multilingual multiracial environment is largely tied to decolonization and, unlike earlier writing from other nations considered in this volume [Canada, New Zealand and Australia], dates mostly from the 1960s. (8)

In this context, they argue, "the transnational takes over from the national and colonial as a space of two-way interaction," as "literary circuits spread into Oceania" $(8,10)$. The transnational dimension of the literatures of Pacific Islands (including New Zealand) is one of the key aspects of the second part of this issue on "Unsettling Oceania." EvaMarie Kröller, in the same book, concludes that the South Pacific Islands, in their utter diversity, may be seen as "a paradigm for the kind of plurality that the national histories 
considered here [i.e. Canada, Australia, New Zealand, and the South Pacific] have struggled to accommodate" (559). Kröller's proposal may be especially relevant to the space that is considered in this issue as Oceania.

More broadly, the issue addresses the multifaceted process of re-imagining Oceania in the contemporary period of decolonisation. The works studied here look simultaneously towards the future and back in time towards the colonial period and the mythical times before that. Australian literature is thus "recurrently afflicted [...] by some deepseated sense of ontological dis-ease," as it continues to free itself from residual colonial ideologies, to reimagine "a nation of self-mythologized 'unsettled settlers" (Huggan VIII, XI). In contemporary New Zealand literature, "writers go back to the colonial past for their subject matter but as a way of reinventing literature or unsettling history, not as a homage or a record but as a source of something new and often disquieting" (Stafford and Williams 941). Indigenous Pacific literatures in English emerged in the late 1960s and early 1970s, in a period of worldwide decolonisation and civil rights protest. While many Pacific writers draw on Indigenous traditions, much contemporary Pacific writing is still engaged with colonialism and its legacies (Keown 7).

The phrase "Unsettling Oceania," playing on the words settling and unsettling, embraces a contemporary movement in postcolonial studies that consists in questioning assumptions that are part of settler societies and cultures. The pun is particularly apt in former settler colonies such as Canada, Aotearoa New Zealand, and Australia.' The focus shifts always more closely towards Indigenous concerns while the notion of decolonisation underlies the image of unsettlement to various degrees. In this view the theoretical concept of "delinking" formulated by Walter Mignolo is quite useful here. It argues that a decolonisation of culture and epistemology is a necessary condition to a non-Eurocentered worldview, which itself is the accepted basis of modern rationality. Mignolo's thesis is that the emergence of a body-politic (to do with race, gender and sexuality) and a geo-politic body of knowledge (to do with subjectivity and knowledge) "introduced a fracture in the hegemony of the theo- and the ego-politics of knowledge, the two standard frames of the colonization of the souls and the minds since the Renaissance [...]" (484). According to Mignolo, geo-politics of knowledge "is affirmed as the re-emergence of the reason that has been denied a reason [...] by the rhetoric of Christianization, civilization, progress, development, marker democracy" that was imposed during Western imperial and capitalist expansion (462, 463). Geo- and body-politics of knowledge are thus seen as "alternatives to the hegemony and dominance of the theo- and ego-politics organizing the modern / colonial world (that is, [...] Europe and the US in their relations of conflict and domination framed by colonial and imperial differences)" (499). Mignolo's ideas tie in with Michelle Keown's comment that

9. To quote a few examples: Unsettled Remains: Canadian Literature and the Postcolonial Gothic, a collection of essays edited by Cynthia Sugars and Gerry Turcotte, puns on the word "settle" to allude to settlers' guilt in Canada. Unsettling Canada: A National Wake-Up Call, by Arthur Manuel and Grand Chief Ronald M. Derrickson, two First Nations leaders, calls for action to support Indigenous sovereignty, contesting the claim of settlers to the land. In Violence Against Indigenous Women: Literature, Activism, Resistance, Allison Hargreaves, who calls herself "an allied settler scholar," proposes to study Canadian Indigenous women's literature and "its capacity to unsettle commonplace settler assumptions about violence and resistance" as well as its role in "sustaining Indigenous communities, readerships, and futures" (x, 19). Rebecca Rice, in Unsettling: Art and the New Zealand Wars, "revisit[s] institutional practices of collecting and exhibiting, past and present, to reflect upon the histories of remembering and forgetting embodied by art from the time of the New Zealand War" (publisher's description online). The theme of the December 2018 conference of the International Australian Studies Association (InASA) in Brisbane is "Unsettling Australia." And so on. 
the "imaginative literature of the Pacific transforms and contests existing narratives of history and culture, particularly those produced by the West" (10). Whether the essays presented here deal with economic and political decolonisation (following military colonisation or the conducting of nuclear experiments for instance) or the decolonisation of cultural representations, all of the authors studied at some stage also put the question of decolonisation in terms of knowledge and epistemology and point out the need to uphold a perception situated through geo-politics and the racialised body.

The five essays in the second part deal with the Pacific Islands (including Aotearoa New Zealand), where the ocean plays a central role in the definition of a changing identity, both local and global. ${ }^{10}$ It is also the case that, as Melissa Kennedy rightly observes, "As a site significantly shaped by migration, indigenous rights, finance, trade and debt, global warming, resource extraction, and nuclear testing, the Pacific registers and reflects with great sensitivity the force of free-market neoliberal globalization, as well as its malcontents" (908).

Kara Hisatake, in "Revising the Settler Colonial Story in Albert Wendt's Black Rainbow," argues that Wendt's dystopian novel is about storytelling and emphasises reading as a decolonial method. The novel revisits the links between nation and narration, addressing the violence of New Zealand's settler colonialism, in contrast with the constructivism of social realist settler novels. It is part of a process of decolonising (his) stories through settler colonial critique and a reassertion of the value of whakapapa, or indigenous genealogy, as a way to incorporate different epistemologies. Mixed identity is thus reframed as contemporary Indigenous Pacific identity.

In "The Nuclear Uncanny in Oceania: James George's Ocean Road," Jessica Hurley considers that indigenous epistemologies are not at odds with the nuclear age but embrace it in their worldview. She thus analyses Māori author James George's 2006 novel Ocean Roads to show how the nuclear uncanny is integrated into the Māori heimlich whakapapa model of genealogy and kinship. This participates in a process of resistance to colonialism in which history is fully integrated, rather than rejected, from a Māori standpoint for decolonisation.

Valérie Baisnée, in “'I'm Niu Voices': Selina Tusitala Marsh's Re-Imagining of a Pan Pacific Space," analyses how the poet Selina Tusitala Marsh, in her 2009 collection Fast Talking PI, reconsiders Pacific Island identity in terms of diversity and hybridity, going against stereotypes and celebrating multiplicity. Baisnée's article illustrates aspects of what Michelle Keown identifies as "strong filial connections between Indigenous Pacific peoples from various ethnic backgrounds" in Aotearoa New Zealand, and also how "many of the 'second generation' Pacific writers who have emerged since the 1990s have drawn inspiration from - and in some cases reacted against - the work of firstgeneration writers such as [...] Albert Wendt [...]" (Keown 9). It further illustrates how the "Pacific" identity Marsh describes means essentially Polynesian and New Zealand.

Marlo Starr, in "Paradise and Apocalypse: Critiques of Nuclear Imperialism in Kathy Jetn̄il-Kijiner's Iep Jältoke," focuses on Marshallese poet-activist Kathy JetñilKijiner's first collection, Iep Jâltok (2017), to address the United States' militarisation of the Pacific Islands. Starr illuminates how the poet evokes the material and psychic impacts of the militarisation of the Pacific, a space that the US wrongly perceives as

10. The other six articles of the issue, on Australian literature, are introduced separately in the first part. 
vacant, reveal-ing from an intimate, personal viewpoint a structure of environmental violence that is part of a global whole.

Otto Heim's “How (not) to Globalize Oceania: Ecology and Politics in Contemporary Pacific Island Performance Arts" also considers slow violence by looking at a range of performance arts (that include performance poetry). Heim starts by retracing the impact of colonisation on the ecology of Oceania, focusing on selected key events, and replacing it in the broader frame of global ecological changes. He then studies two geo-cultural areas and two cases of how artists respond to ecological colonisation, first by looking at Guam and the place of performance of songs and dances, mainly Craig Santos Perez's experimental poetry of protest against US military expansion in the several volumes of the long poem from unincorporated territory. The second case study comes out of Fiji, where concern about sustainable development is manifest and has shaped a number of artistic projects and festivals. Heim also points out the role of the Oceania Centre for Arts, Culture and Pacific Studies and of the University of the South Pacific. He focuses on Moana: The Rising of the Sea, a 2013 show written and directed by Vilsoni Hereniko in which Kathy Jetnil-Kijiner's poetry figures prominently. Heim concludes that such activist art is part of democratic politics at both the local and the global levels, and foregrounds Indigenous Pacific values and practices.

\author{
Christine LORRE-JOHNSTON ${ }^{11}$ \\ University Sorbonne Nouvelle - Paris 3, THALIM
}

\title{
Works Cited
}

Brunt, Peter, and Nicholas Thomas, ed. Oceania. London: Royal Academy of Arts, 2018.

Frame, William, with Laura Walker. James Cook: The Voyages. London: British Library, 2018.

Howelds, Coral Ann, Paul Sharrad, and Gerry TurcotTe. Introduction. The Novel in Australia, Canada, New Zealand, and the South Pacific since 1950. Ed. Coral Ann Howells, Paul Sharrad, and Gerry Turcotte. Oxford: Oxford UP, 2017. 1-10.

Huggan, Graham. Australian Literature: Postcolonialism, Racism, Transnationalism. Oxford: Oxford UP, 2007.

-. Colonialism, Culture, Whales: The Cetacean Quartet. London: Bloomsbury, 2018.

Hargreaves, Allison. Violence Against Indigenous Women: Literature, Activism, Resistance. Waterloo: Wilfrid Laurier UP, 2017.

Hau'ofa, Epeli. We Are the Ocean: Selected Works. Honolulu: U of Hawai'i P, 2008.

Kennedy, Melissa. Introduction. All that Glitters Is Not Gold: Pacific Critiques of Globalization. Ed. Melissa Kennedy and Janet Wilson. Spec. issue of Interventions. 19:7 (2017): 907-13.

Keown, Michele. Pacific Islands Writing: The Postcolonial Literatures of Aotearoa/New Zealand and Oceania. Oxford: Oxford UP, 2007.

Kröller, Eva-Marie. "Literary Histories." The Novel in Australia, Canada, New Zealand, and the South Pacific since 1950. Ed. Coral Ann Howells, Paul Sharrad, and Gerry Turcotte. Oxford: Oxford UP, 2017. p. 544-59.

Manuel, Arthur, and Grand Chief Ronald M. Derrickson. Unsettling Canada: A National Wake-Up Call. Toronto: Between the Lines, 2015.

Mignolo, Walter. "DELINKING: The rhetoric of modernity, the logic of coloniality and the grammar of de-coloniality." Cultural Studies 21:2 (2007): 449-514.

Oceania: Imagining the Pacific. Wellington: City Gallery Wellington Te Whare Toi, 2011.

ReiHana, Lisa. In Pursuit of Venus. Auckland: Auckland Art Gallery Toi o Tāmaki, 2015.

Rice, Rebecca. Unsettling: Art and the New Zealand Wars. Gordon H. Brown lecture, 14. Wellington: Art History, Victoria U, 2015. 
SARR, Felwine, and Bénédicte SAVOY. Restituer le patrimoine africain : vers une nouvelle éthique relationnelle. November 2018. <https://bj.ambafrance.org/Telecharger-l-integralite-du-Rapport-Sarr-Savoysur-la-restitution-du>.

Sugars, Cynthia, and Gerry Turcotte, eds. Unsettled Remains: Canadian Literature and the Postcolonial Gothic. Waterloo: Wilfrid Laurier UP, 2009.

Stafford, Jane, and Mark Williams. The Auckland University Press Anthology of New Zealand Literature. Auckland: Auckland UP, 2012.

Wendt, Albert. “Towards a New Oceania.” Mana Review 1.1 (1976): 49-60. 